\title{
Innovations for union renewal
}

\author{
Gregor Murray* and Jeremy Waddington**
}

\begin{abstract}
Throughout much of the industrialised world, the terms of the post-war settlement consolidated the position of trade unions and allowed sufficient scope for unionists to bring influence to bear on economic and social development. In Europe the state strengthened trade unionism through supportive legislation and by engaging in different forms of exchange around macroeconomic policy issues and welfare provision. Such exchange was usually founded on Keynesian assumptions. The expansion of Fordist mass production regimes allowed trade unions access to a growing and relatively homogeneous membership, and encouraged employers to engage with trade unions in centralised or industrial collective bargaining. Within the terms of this post-war settlement, trade unions acted politically to improve welfare provisions and to bargain for improvements in the standard of living of members. The precise nature and scope of this activity was influenced by the national regulatory regime within which it took place and the structure of the union movement concerned, but the point remains that trade unions were embedded in, and were integral to, the different national regulatory regimes.
\end{abstract}

The end of the long post-war period of stable growth during the mid-1970s led to a number of inter-related developments that challenged the position of trade unions. These included acceleration in the pace of economic internationalisation, the more widespread adoption of neoliberal policies, changes to the character of work and the reform of production regimes. Furthermore, processes associated with 'tertiarisation' resulted in changed borders within labour markets, as the industrial sector declined and employment in the public and, latterly, private services expanded. Distinctions between the three sectors also became more opaque. Many of the processes of 'social modernisation' eroded the traditional sociocultural milieus that underpinned the strongholds of trade unionism. The male 'breadwinner' model, on which much trade union organisation was based, became increasingly inappropriate. Trade union membership and density declined as a result of these developments, with the consequence that specific unions suffered severe limits to their material and political resources.

In combination, these developments have led some to suggest that trade unions are no longer relevant and are anachronistic and that where they persist they do so in many

* Director of the Interuniversity Research Centre on Globalization and Work (CRIMT) and Professor in the School of Industrial Relations at the University of Montreal

** Professor of Industrial Relations at the University of Manchester and Project Coordinator for the European Trade Union Institute for Research, Education and Health and Safety (ETUI-REHS), Brussels 
instances as hollow shells (Regini 2003). It has also been argued that the social movement aspects of trade unionism are redundant, as workers now see trade unions as a source of specific services rather than as a vehicle for social change (Schroeder and Weßels 2003); just as it has been suggested that unions are faring poorly precisely because they have become providers of services and are failing to be connected with the new social and community movements likely to spark social change (Turner 2005). Yet others highlight important changes in the way work and employment are managed and point to the failure of trade unions to embrace new agendas, be it in terms of the workplace or labour market identities (Edwards and Wajcman 2005).

It was with these challenges in mind and in an effort to build bridges between the most current academic research on labour and employment issues and the experiences of union activists and staff that the Interuniversity Research Centre on Globalization and Work (or CRIMT, which is the French language acronym for the Centre de recherche interuniversitaire sur la mondialisation et le travail) convened an International Colloquium on Union Renewal in Montreal in November 20041. The organisers felt the need to reinforce the links between different research communities, across national boundaries and between those engaged in union renewal and those in the research community analysing it. Many organisations endorsed these objectives with enthusiasm, as was evident in the support from both union and research organisation partners, notably the ETUI. In response to specific invitations and an international call for papers and union renewal experiences, 250 people from 15 countries participated, including academics as well as trade unionists and other community partners. Many of the 90 contributions are available on the CRIMT website (http://www.crimt.org/) and a dedicated interactive site on union renewal (http://www.crimt.org/Unionrenewal.html). Articles from the colloquium are also appearing in five labour and industrial relations journals across the world as well as a collection of studies on union renewal in Canada (Kumar and Schenk 2005) ${ }^{2}$. Of course, the objectives of the CRIMT Colloquium and those of the ETUI are so compatible that it was a natural fit to find a place for the expression of some of the most interesting research results in this special issue of Transfer $^{3}$.

The burgeoning literature on union responses to these challenges emphasises union 'renewal', 'revitalisation', 'remaking' or 'rekindling'. In most cases the literature is national rather than comparative, focuses on individual trade unions rather than confederations or Global Union Federations and tends to view renewal as comprising

1 This initiative was part of a Major Collaborative Research Initiative project, initiated by CRIMT and funded by the Social Sciences and Humanities Research Council of Canada, entitled 'Rethinking Institutions for Work and Employment'.

2 In addition to this special issue of Transfer, see forthcoming issues of Just Labour (2005), Labor Studies Journal (2006), La Revue de l'IRES (2006) and Relations industrielles/Industrial Relations (2006).

3 The editors of this special issue wish to thank the ETUI for its support for the Colloquium and the Transfer editorial board for reviewing the proposal and the texts. 
activity at different levels of operation (Heery et al. 2004) or within different fields of operation (Behrens et al. 2004). This issue of Transfer incorporates aspects of these analyses in so far as it assesses union attempts to renew organisation at different levels (global, Hammer, and Lévesque and Dufour-Poirier; industry, Contrepois and Jefferys; region, Jobert; and local and workplace unions, Brown Johnson and Jarley, and Lévesque and Dufour-Poirier); and in a variety of fields of operation (new social movements, Le Queux; young workers, Brown Johnson and Jarley; women and immigrant workers or racial minorities, Yates).

The reconfiguration of global production systems is certainly one of the most visible faces of the restructuring of work and employment with which trade unions now have to contend. Previously fixed boundaries of firms and their spatial location are much more malleable as new technologies modify the nature of relationships within and between firms and permit the kind of extensive integration of production activities which were previously only imaginable in vertically integrated firms. Similarly, greater capital mobility and the dismantling of trade barriers open up the possibility of shifting activities to lower cost production regimes and stimulate the development of ever more sophisticated international logistical systems. The expansion of the EU to central and eastern Europe offers telling examples of this phenomenon across a wide range of industries. Nor is this phenomenon limited to Europe as firms in the US and Canada outsource and/or relocate activities to Latin America and Asia and firms in Europe relocate activities outside of the EU, either on the periphery (as in Turkey, the former Soviet republics, North Africa or further afield to lower cost locations in Asia). The limits of traditional systems of worker representation - be they national or European - are evident in the face of these trends. Several of the contributions to this issue of Transfer enhance our understanding of this phenomenon.

International union activity is of course viewed as a prerequisite to union renewal in the context of globalisation, the development of international regulatory regimes and the influence of multinational companies (Harrod and O'Brien 2002; Munck 2002; van Roozendaal 2002). A key institutional response on the part of Global Union Federations has been to negotiate International Framework Agreements. The paper by Hammer examines the emergence and content of these new global collective agreements in order to assess the adequacy of this kind of union response to larger trends in the internationalisation of goods and services. The extent of these agreements is still very limited (Hammer analyses 38 such agreements in June 2005); so caution is necessary in assessing a phenomenon which has, for the most part, been the product of the last three years. Hammer finds two types of agreement existing under the same label: 'bargaining' agreements tend to emerge in producer-driven supply chains (such as automobile manufacturing), where unions are more strongly represented, and resemble traditional collective agreements, no matter how limited in scope; 'rights' agreements are more typical of buyer-driven supply chains (such as retail distribution), where unions are much less in evidence and the agreement is often an extension of a corporate code of conduct. In either case, the relative success of such 'platforms' very much depends on the mobilising and networking capacities of trade unions. 
One of the most intractable problems for unions from the Global North (i.e., the most highly developed economies) is their relationship with unions in the Global South (i.e. the less developed and newly industrialising economies). So often much less organised and institutionalised than their Northern counterparts and too often permeable to employer and other influences that inhibit their autonomy, are unions in the South to be seen as beneficiaries of philanthropic doses of solidarity from the North or global competitors for a limited supply of jobs? The reality is undoubtedly somewhere between these two positions, with the discourse pulling towards solidarity while the practice is more sensitive to competition. Faced with this dilemma, the prevailing union response from the North is the need to reinforce free collective bargaining and to enhance the capacity of Southern unions. But how do Southern unions experience these same issues? Through an examination of the seven affiliates of the International Metalworkers' Federation in Mexico, the paper by Lévesque and Dufour-Poirier sheds new light on how unionists in newly industrialising economies experience the international in a context where Global Union Federations are engaged in capacity-building exercises for their Southern counterparts. Lévesque and Dufour-Poirier find a range of local union responses: from primarily local and defensive to internationalist and proactive in orientation. Like Hammer, their response suggests that these orientations are the result of greater or lesser degrees of union power, which reflect both existing union capacity and specific circumstances. They find that international alliances can represent a significant source of union renewal, provided that the Southern union (Mexico in this case) has sufficient power to begin with. When this is the case, enlarged conceptions of solidarity and interest can emerge and this would seem to be a conclusion as applicable to unions in the North as in the South.

Contrepois and Jefferys address two key questions. How can trade unions respond to relocation? To what extent can unionists put forward alternative policies to challenge the new priorities imposed by management? These questions are explored in the context of national union responses to developments within banking in France and the UK. The comparative tale of continuing union restructuring in the two countries highlights the difficulties for unions to contest globalisation in effective ways on behalf of their members. While pointing to efforts to develop a critique of trends in the industry and to develop a more transnational vision of union action, the paper highlights the difficulties faced by unions in connecting with their membership on some of the key issues and, particularly in the light of the increasing importance of general union structures, of organising effective transnational coordination between national unions in their industry. The authors believe that the ability to do so will depend on both more effective organising at local level and the political will to develop alternative visions.

The question of alternative visions is at the heart of the paper by Le Queux who seeks to understand the dialogue of the deaf between institutionalised union movements and the new social movements as typified by the political vitality of the anti-globalisation movements. His account of these differing logics is based on extensive participant research with the social movements of anti-globalisation, many of whom are also young workers, as well as close observation of some of the avenues of union revitalisation in 
France. Le Queux identifies different fault lines that differentiate and inform the two perspectives: utopia as opposed to regulation; participative as opposed to representative democracy; organic and inclusive organisational principles as opposed to corporatist or compartmentalised representation; and direct and theatrical forms of action as opposed to institutionalised or ritual forms of conflict such as collective bargaining. While this is a heuristic exercise seeking to crystallise quite different perspectives, Le Queux's sympathies clearly lie with the transformative potential of the politics of the 'anti-globalisationists'. Similar in this respect to the argument developed by Contrepois and Jefferys, he argues that institutionalised union leaderships are caught in a dilemma as regards their incapacity to develop alternative visions of globalisation and hence the interest in embracing the transformative politics of the new social movements. While not all readers will embrace his self-avowedly over typified representation of institutional union leaderships, his analysis of the underlying logic of anti-globalisation movements and its contrasts with more traditional union approaches will not only prove insightful for all but challenges us to think about the dynamics of the 'political' as the heart of union revitalisation.

Transformations in regulatory regimes are reordering levels of collective bargaining throughout national economies (see, for example, Marginson and Sisson 2004). Jobert's account of French trade unionism is of particular interest in coming to terms with this change. French trade unionism is notably weak in terms of its low levels of membership and virtual absence in so many workplaces. Jobert identifies three further trends exerting a destabilising influence on French trade unions: the decentralisation of some of the activities of the French state; the move from industry to enterprise or company bargaining and, further still, to workplace bargaining; and the decomposition of vertically integrated production systems into regional networks of producers. While these changes can be viewed as real constraints on the mechanisms for collective representation and a further source of union decline in France, Jobert's analysis suggests that they also open up new opportunities for union action at a regional level. Drawing on a number of recent French experiences to protect jobs and ensure economic development initiatives such as training, Jobert highlights an emerging space and important impetus for regional dialogue on the part of social partners, which might well constitute a source of renewal for French trade unions. Unlike traditional forms of union-management dialogue, however, these regional variants are more likely to involve a wider range of actors and to entail fairly complex and variable asymmetries between forms of representation based on the workplace, the firm, the industry and the region as social actors look for new ways to regulate work. This analysis is certainly consistent with a broader set of arguments on the reregulation of labour in a global era and the possible scope for new sites of negotiation about work and the emergence of new social actors.

Debate has also focused on the range of tactics and strategies adopted by trade unionists within different national regulatory regimes to renew organisation. Servicing, organising, partnership at work, social partnership, community unionism and social movement unionism are among the range of options suggested within the literature (Wills 2002; Waddington 2000; Shostack 1991; Dribbusch 2003). In the light of post-modernist 
accounts of declining civic mentality and frayed social capital in the United States, Brown Johnson and Jarley examine the possibility of using the notion of social capital to understand a potential avenue for the renewal of trade unions. Drawing on experiences in the retail food and meat processing industries with a major US union in these industries, they argue that if unions are to maintain and to build union knowledge and participation 19th century methods of organising around people by establishing dense social networks should be introduced to focus on mutual aid in addition to the provision of support within the workplace. Such dense networks among young workers and between young workers and local union representatives are shown to be central to the capacity of the union to mobilise workers in support of economic and political goals. Their conclusions certainly speak to the problems experienced by unions in engaging younger workers in traditional collective projects. These problems, moreover, are not unique to younger workers. As observed in a number of contributions to this issue of Transfer and more generally in the union renewal literature (see, for example, Lévesque and Murray 2002), the challenge of developing local union power is linked to internal cohesion and membership mobilisation. The paper by Brown Johnson and Jarley suggests that social networks offers one of the keys to understanding this dimension of union renewal.

One of the major criticisms of contemporary union movements concerns their inability to come to terms with the social composition of an evolving labour market. Women are much more visible in the formal labour market. So too are workers of minority racial and ethnic backgrounds. If globalisation is associated with a polarisation of labour market fortunes - with rewards to the winners and punishment for the losers - it is precisely these groups that are often ghettoised into lower-paid jobs and deprived of effective collective representation. A core question then concerns the ability of unions to come to terms with and embrace both the polarisation and greater diversity of contemporary labour markets. This challenge is at the heart of the paper by Yates who argues that any union renewal project must come to terms with this challenge. Her analysis is especially interesting because she uses the case of one of the supposedly better examples of union diversification in the light of labour market change. The Canadian labour movement has probably been seen to make more progress in integrating women, immigrant workers and workers of other races than many national labour movements. However, Yates advises caution here. In a systematic analysis of different facets of union activities, including organising and participative structures, she suggests, in the light of compelling labour market trends, that the kinds of changes required to address imbalances in the representation of these workers hardly scratch the surface. The fundamental argument is that unions, in Canada and elsewhere, must embrace and reflect the aspirations of new labour market identities if they are to meet the challenge of renewal.

Each of these seven papers then provides much food for thought, highlighting a particular level of analysis or a field of action in the continuing debates over union renewal and revitalisation. Together, they speak to the multidimensional nature of the challenges at hand and point to key avenues for experimentation and innovation in an effort to build a collective response to the continuing restructuring of the global economy. 


\section{References}

Behrens, M., K. Hamann and R. Hurd (2004) 'Conceptualizing Labour Union Revitalization', in C. Frege and J. Kelly (eds.) Varieties of Unionism: Strategies for Union Revitalization in a Globalizing Economy, Oxford: Oxford University Press.

Dribbusch, H. (2003) Gewerkschaftliche Mitgliedergewinnung im Dienstleistungssektor, Wuppertal: Edition Sigma.

Edwards, P. and J. Wajcman (2005) The Politics of Working Life, Oxford: Oxford University Press.

Harrod, G. and R. O’Brien (2002) (eds.) Global Unions?, London: Routledge.

Heery, E., G. Healy and P. Taylor (2004) 'Representation at Work: Themes and Issues', in G. Healy, E. Heery, P. Taylor and W. Brown (eds.) The Future of Worker Representation, Basingstoke: Palgrave Macmillan.

Kumar, P. and K. Schenk (eds.) (2005) Paths to Union Renewal: Canadian Experience, Calgary: Broadview Press.

Lévesque, C. and G. Murray (2002) 'Local Versus Global: Activating Local Union Power in the Global Economy', Labor Studies Journal, 27 (3), 39-65.

Marginson, P. and K. Sisson (2004) European integration and industrial relations: Multilevel governance in the making, Basingstoke: Palgrave Macmillan.

Munck, R. (2002) Globalisation and Labour, London: Zed Books.

Regini, M. (2003) 'Tripartite Concertation and Varieties of Capitalism', European Journal of Industrial Relations, 9 (3), 251-263.

Van Roozendaal, G. (2002) Trade Unions and Global Governance, London: Continuum.

Schroeder, W. and B. Weßels (2003) Die Gewerkschaften in Politik und Gesellschaft, Wiesbaden: Westdeutscher Verlag.

Shostack, A. (1991) Robust Unionism: Innovations in the Labour Movement, Ithaca: ILR Press.

Tillman, R. and M. Cummings (1999) The Transformation of U.S. Unions, Boulder: Lynne Rienner Publishers.

Turner, L. (2005) 'From Transformation to Revitalization: A New Research Agenda for a Contested Global Economy', Work and Occupations, 32 (4), 383-399.

Turner, L., H. Katz, and R. Hurd (2001) Rekindling the Movement, Ithaca: Cornell University Press.

Waddington, J. (2000) 'Towards a Reform Agenda? European Trade Unions in Transition', Industrial Relations Journal, 31 (4), 317-330.

Wills, J. (2002) Union Futures: Building Networked Trade Unionism in the UK, London: Fabian Society. 